\title{
THE INTELLECTUAL AS SOCIAL REFORMER: MACHIAVELLI AND THOMAS MORE*
}

Y SUBJECT in these lectures is the intellectual as teenth-century figures.

We may do well to start with the simple fact that the intellectual is almost inevitably a reformer. If a man sets himself to ponder hard and long about some big problem-such as the nature of God or of man or of society or of the universe-if he honestly tries to take all the relevant facts into account and to develop an intelligible theory about his problem, as a good intellectual does, then he is going to become dissatisfied with what he finds. If it is God and the universe that interest him, he may have to limit himself to criticizing other people's theories. But if it is man and society, he will be tempted to point out a few actual things that are wrong, why they are wrong, and how they can be remedied. Seeing things whole generally has this effect. No sooner does Mr. Toynbee get well into his vast Study of History, for instance, than we realize that he is pointing out quite a few things that are wrong with our Western society and calling on us to mend our ways.

At the dawn of the modern era, two supremely articulate figures happened to exemplify most of the significant problems of the intellectual as social reformer: his strengths and weaknesses, how he comes by his ideas, what gives him his social passion, and what lends his work enduring quality. They were Niccolò Machiavelli and Thomas More. Their lives and writings are perfectly familiar to educated people,

- Two lectures prepared for delivery in April, 1957. Because of Professor Harbison's illness at the time scheduled for the lectures, they were not given. They are printed here as prepared for oral presentation. 
and I do not expect to tell you any facts about either that you do not already know. What I propose to do is to look at them from a somewhat fresh perspective: as pioneers of the idea that society-not individuals alone-can be changed, and that for various good and sufficient reasons, it must be. The fact is that Machiavelli and More inaugurated modern political thinking by sensing and facing what proved to be some of the most crucial problems of our modern Western society. Neither had much influence on the technical political theory of his day. But between them they gave us two words which have absorbed a heavy freight of meaning in the intervening centuries: "Machiavellian" and "Utopian." And this is one measure of their stature and importance, even if Machiavelli was no "Machiavellian" and More no "Utopian"-as they were not. Together they represent the first tough-minded but imaginative thinking about modern political, social, and economic problems. And together they symbolize the perennial tension between the two polar attitudes on these problems: that of the "realist" and that of the "moralist."

It was worth recalling some of the main contrasts and coincidences between the two before we go further. Europe was culturally and spiritually more united in 1500 than it is today, but there were sharp contrasts between Machiavelli's Italy, with its welter of wealthy independent cities, and More's England, one of the better-run national monarchies of its day. Machiavelli was born in Florence in 1469; Thomas More in London nine years later. They never met nor (so far as we know) ever read each other's works. Machiavelli spent his younger years in active civil service, his later years in bitter enforced retirement. More spent his early years in private life and long resisted the call to service of his King, which he 


\section{The Intellectual as Social Reformer}

entered in his later years. Machiavelli was driven to write by being dismissed from office, More (in part) by being invited to assume office. Machiavelli wrote his major works in Italian for the perusal of a few and never published them during his lifetime; More wrote his most famous book in Latin and published it immediately to the delight of the learned all over Europe. They wrote simultaneously. Machiavelli dedicated his final version of The Prince to Lorenzo de' Medici in 1516, the same year More's Utopia came off the presses at Louvain. Machiavelli was a thorough pagan who nevertheless never formally rejected Christianity, saw his son enter the priesthood, and died with a priest at his bedside. More was one of the great Christians of history, who nevertheless remained a layman all his life and is remembered today as much for his more worldly qualities as for his sainthood-his humor, his family life, his zest for classical learning, and his shrewd grasp of social problems. Machiavelli died a disappointed man in 1527, before word could reach him that another man had been given the public office he had long coveted. More died triumphantly on the scaffold in 1535, "the King"s good servant," as he put it, "but God's first.".

Polar opposites, you may conclude-and there is much truth in this. But it is important not to forget what they had in common. Each of them represented a combination, not too common even in the Renaissance, of scholarly tastes and practical experience, of humanistic accomplishment and civil service. Each was a thorough humanist in the contemporary sense of the word; that is, one who is convinced of the importance and relevance of classical study and who devotes much of his time to it. At the same time, each was saved from the dilettantism of many contemporary humanists by his strong practical interests. Both believed in the efficacy of 
appealing to men's intelligence, but neither believed that an intellectual could change the world merely by writing books. Both wrote with exceptional clarity, and yet both managed to set their readers to arguing violently about what they really meant to say. The major conclusion of these arguments, which are now over four centuries old, seems to me to be this: that Machiavelli was a curiously idealistic realist, and that More was a strikingly realistic idealist. Polar opposites with much in common, in other words.

\section{Machiaveliti}

It is hard to describe the conditions surrounding the birth of modern political thought at the close of the Middle Ages without grossly distorting the picture by oversimplification. Perhaps the most direct way is to say that the political thought of the brilliant generation that included Machiavelli and More was the result of two things: the social tensions accompanying the dissolution of medieval institutions, and the simultaneous impact of the classical revival.

At the close of the fifteenth century the medieval respublica christiana was disintegrating rapidly. The pattern was still there in men's minds, the pattern of a hierarchical society headed in its temporal aspects by the Emperor and in its spiritual aspects by the Pope. Most men still assumed that this pattern of feudal and ecclesiastical organization was God's design for Christendom. But the discrepancies between the form and the reality were growing at a bewildering pace. In parts of Europe-North Italy, for exampleeconomic power lay in fact with a class which had no place in the pattern, the "middle class" of merchants, industrialists, lawyers, and scholars. Political power rested in an institution utterly unknown to the medieval pattern, the sovereign, ter- 
ritorial state. Within the busy, swarming cities of Italy there were careers wide open to talent-and hot competition to excel, whether as scholar or artist, professional soldier or political despot. And between the city-states there was a constant jockeying for territory and Lebensraum, a struggle for power untempered by any respect for higher authority of Pope or Emperor. Respect for legitimate authority, for what Burke would later call "precedent, prescription, and antiquity," was still dominant in much of Europe. But in Italy it yielded to admiration for talent and determination, inventiveness and virtuosity. In Burckhardt's famous phrase, the state was becoming "a work of art," not something given by God or rooted in immemorial custom and tradition, but something man could mould and shape and form to suit his needs. In fourteenth- and fifteenth-century Florence, revolutions seemed to be the chief outdoor sport, and constitutionmaking the chief indoor amusement. Diplomacy too became an "art," the product "of conscious reflection and calculation," as did warfare and painting and business practice. It has often been remarked that in all this, Italy was a kind of microcosm of the modern world.

In other words, something like the modern sovereign, territorial state and something like modern capitalistic practice in commerce, industry, and even agriculture had appeared in the Europe of 1500. But there were no categories of thought through which these developments could be understood, let alone controlled. The Middle Ages had an unshakable sense of right and justice, but never any very effective way of enforcing the right. There was always a principle to cover every incident, a law to apply to every case, but there were no effective sanctions. The typical early medieval society, someone has said, was "all law and no 
government." Now here were strong rulers and powerful merchants creating a kind of illegitimate order of their own. Was it enough simply to put them down as "tyrants" and "despots," "monopolists" and "usurers," using the traditional categories of thought? "The old order was not good," Machiavelli wrote, "and none of us have known how to find a new." He was speaking of the art of war, but the remark might serve as a symbol of the bewilderment of the thinkers of his generation as they searched for some new way of understanding what was going on around them.

Our twentieth-century attitude in such a situation, I suppose, would be to say: "Get our economists and political scientists on the problem; hire a staff, apply for a foundation grant, and rent an electronic calculator; if the money holds out, we should have the answers in a few years." Fortunately or unfortunately, there were no such methods or resources available in the generation of Machiavelli and More. What was available was a new store of ancient political and social wisdom, and to this they turned with eagerness. Men began to reread Aristotle and Cicero, Thucydides and Polybius, Livy and Tacitus, with new purpose and understanding. Here was a literature concerned with politics and morals, with civil and foreign war, with tyranny and revolution, with justice and might-in other words, with every aspect of the struggle for power, among individuals within the state and among states themselves. To thoughful fifteenthcentury readers all this was exciting-far more relevant than medieval chronicle or scholastic philosophy-and of course more practical than a "scientific method" still in its infancy. Their contemporary experience enabled them to understand the ancient writers, as schoolmen two centuries earlier could not have done; and their reading in turn deepened their 
understanding of contemporary politics and diplomacy. Modern political thought, in other words, resulted from the coincidence of rapid social change with the classical revival at the close of the Middle Ages. As new economic and political practices came into almost intolerable conflict with older habits of thought, a relatively untapped storehouse of social insight was discovered, or rediscovered. The Prince, The Discourses on Livy, and Utopia were not the only products of this fruitful coincidence, but they were perhaps the greatest.

So far we have talked in very general and abstract terms. We have left out the factor which, to men of the Renaissance at least, was always the most important: the human factor. Unless these social tensions and political problems somehow got under one man's skin, unless the man concerned was endowed with more than the usual perspicacity and sensitivity, and unless something happened to set this man writing, nothing so grandiose as "the birth of modern political thinking" would take place, of course. Therefore it is very relevant to our inquiry to ask what sort of character and experience Machiavelli brought to his writing, and how he came to write as he did.

The two most prominent traits in his character appear very early: his carefully-nurtured habit of seeing things as they are rather than as they might be, and his contradictory passion to see his beloved city of Florence in the ideal state of civic peace and diplomatic security which he hoped might be, but which obviously did not exist in the 1490's. One of the earliest glimpses we get of him is in a letter he wrote to a friend in March, 1497, describing Savonarola's sermons. Machiavelli saw that the prophet's public addresses were becoming more hysterical as fear for his own power 
grew. "He began," writes the cool young observer, "with terrifying horrors, showing with arguments that must have been very effective with people not trained to thinking, that his followers were very fine people while his opponents were the worst sort of rascals. He went on to any limit that seemed likely to weaken the hostile party and strengthen his own." There were two armies, Savonarola argued: that of the Lord, which included him and his own followers, and that of Satan, which was composed, of course, of his enemies. ${ }^{2}$ Savonarola, the "unarmed prophet" of The Prince, obviously made a deep impression on Machiavelli, but not as a model of intelligence or statesmanship.

A month after Savonarola's execution, in June, 1498, Machiavelli got his first job with the republican government of Florence, and for the next fourteen years he served as Chancellor and Secretary to the ruling council of the city and as diplomatic envoy on numerous legations-to Paris, to the Emperor, to the Pope, to Caesar Borgia, and to many of the neighboring city-states. The picture we get of him during these years is that of an exceptionally acute observer of the political scene, unquestioningly faithful to his government although sometimes critical of its policies, always conscious of the weakness of the city-state he represents, always anxious to compensate by sheer intelligence for this weakness by turning up ingenious solutions to unsolvable problems, yet usually aware of the grim limits on Florentine freedom of action. He is generally second-in-command on any given legation, not first-which suggests that his bosses valued his brains above his judgment. Occasionally he compares someone's policy with that of the Roman Republic in similar circumstances, to the advantage of the ancients, which suggests that although he is not a man of wide culture, he is reading the ancient historians. 


\section{The Intellectual as Social Reformer}

His two constant preoccupations are the disunity at home and the weakness abroad that make his government's job the nightmare that it is. The Pazzi Conspiracy of 1478, that lurid plot to murder Lorenzo the Magnificent in church, had made a deep impression on him at the age of nine, and all his life he was to be concerned with the problem of parte, or factions, and their disintegrating effect on the State. But an even deeper impression had been left on him by the invasion of Italy in 1494 by Charles VIII of France, the invasion that first revealed the startling inferiority of a land of petty, warring city-states to a well-organized national monarchy." Five more times Italy was to be invaded before Machiavelli's government fell-once more by France, twice by the Emperor, and twice by Spain. The last attack by Spain in 1512 overthrew the republican regime in Florence and restored the Medici to power. In her weakness Florence had made an alliance with France, and in a stubborn display of civic honor, she stuck by the alliance long after it was clear that Spain was going to beat France out for control of the Italian peninsula. In another display of personal honor, Machiavelli's close friend and superior, Piero Soderini, refused to use unconstitutional means to save himself and his government in the crisis. In August, 1512, Soderini fled. Some two months later Machiavelli was dismissed from office. Two months after this, a plot to destroy the new Medici rulers was discovered, Machiavelli's name was found on a list of those to be approached, and Machiavelli himself was imprisoned and tortured to reveal what he knew. Released in February, 1513, he retired to a house of his in the country ten miles south of the city, at Sant' Andrea, where he had a tantalizing glimpse of the Duomo from his garden. And here he was left to put together the broken pieces of his life as well as he could, with a wife and four children to 
support, no job, and no visible prospects of getting one.

His letters during this crucial year 1513 to his friend Vettori (who was Florentine ambassador at Rome) and to Soderini (who had fled to Dalmatia) give fascinating glimpses of how a disappointed civil servant of a third-rate republic became the first modern analyst of political power. He was bored, frustrated, and resentful, worried about where the next meal was coming from, and acutely homesick for the world of politics and diplomacy which was his life's blood. Occasionally he would visit the city, but since he was on the outside looking in, this was almost worse than staying in the country. There he would leave the house in the mornings and try to kill time by chatting with his wood-cutters for a while. He would have a book under his arm-Dante, Petrarch, or Ovid-and for a while he would read. Then he would walk down to the local tavern, talking eagerly to everyone he'd meet on the way, "asking news of their towns, and listening to all sorts of stories as throwing light on the varying tastes and whims of men," he says. Then home for dinner at noon, then back to the tavern, where he would play cards with a butcher, a miller, and a couple of bakers the rest of the day. The stakes were small, but the emotion ran high-“just one battle after another with boundless rages and personal insults." "So with these lice clinging to my person," he writes, "I keep my brain dusted off somewhat and provide a vent for the cruelty of my lot," hoping the Fates would soon feel ashamed of themselves for what they had done to him."

He knew perfectly clearly that he was fitted for one career and one only. At forty-three he could not become a merchant or farmer overnight. If only he could talk to Vettori, he writes. "Fortune has so devised that since I cannot talk 
of the silk trade or the wool trade or of profit and loss, I have to talk of politics. I have only one choice: either to talk of politics or to take a vow of silence." His mind runs restlessly over recent events-every state breaking treaties but Florence, every statesman forgetting the ordinary rules of morality but Soderini with his constitutional scruples. He has come to the conclusion, he writes Soderini, that the sole criterion of policies should be their results, not the means used to attain them. The same end can be attained by different means, just as you can get to the same place by different roads. "Just why different procedures should now help and now hinder, I do not know," he writes, "but I would like to know." He suggests the answer is that "times and circumstances" change, and that the means suitable for one time are disastrous for another. ${ }^{6}$ Vettori asks him what he thinks of the latest move of Ferdinand, King of Spain. Isn't it foolish? Machiavelli jumps at the chance to put his rusting intellect to work and writes ten pages in reply. There is really no problem, he says, if you see that Ferdinand is not much of a statesman-just lucky. His letter will seem a jumble, he concludes apologetically, but he is in the country, never sees a human face (Machiavelli was always given to exaggeration), and knows "nothing of what is going on in the world." Later he argues that Vettori overrates Venetian power; the real danger to Italy comes from the Swiss and the French. "I don't know just what Aristotle says about countries that have been destroyed. What interests me more than theory is what is, what has been, and what may reasonably happen."

Then in the most famous letter he ever wrote (10 December 1513) ${ }^{\circ}$ Machiavelli tells Vettori how when evening comes, he is in the habit of putting off his soiled clothes, 
putting on his court dress, and spending four hours of uninterrupted bliss in the company of his favorite classical authors. With them he partakes of that food which alone he can call his own and for which he was born, he says. He asks them questions, and they answer. Since Dante says there is no knowing apart from remembering, he has put down on paper some of the things he has learned from these older and wiser minds. "I have written a pamphlet which I am calling On Principalities. In it I go as deeply as I can into the subject, discussing the definition of monarchy, how many kinds of monarchies there are, and how they are won, held, and lost. . . . Any head of a state, and especially a new one, should find it interesting." He explains frankly that he is dedicating it to Giuliano de' Medici because he desperately needs a job and hopes the Medici will give him one. "Anybody, it seems to me, should be glad to have the services of a man who has acquired so much experience at the expense of other employers. Of my trustworthiness there could be no doubt. Having so long kept faith with people, I would not be likely to begin betraying now. A man who has kept his word loyally for forty-three years, as I have, could not change his nature very easily. The fact that I am a poor man is proof of my loyalty and honor." Four times the word fede (faith) occurs in these last sentences..$^{10}$ Obviously the writer is deeply concerned to impress even on his friend, who must know it, that patriotism and his pledged word come before party loyalty with him.

This then was the origin of The Prince. Perhaps it is evident from this account why those who have read the book over the years have argued-and still argue violentlyover its purpose and meaning. Was it simply a cool, disillusioned analysis of how to get and hold on to power, with 
the last patriotic chapter added as a sort of afterthought to give the analysis some respectable use? $\mathrm{Or}$ did it, on the contrary, all lead up to the last chapter? Was it an honest and passionate appeal to the Medici to become the saviors of Italy from the foreign barbarians? Did the author really mean what he said about playing the beast rather than the man, seeming to have the private virtues but not being hampered by them, breaking faith if it was to your advantage? Was this the Machiavelli who was so proud of his own word once given and of his republic's reputation for good faith? Was he perhaps being satiric in The Prince, showing up despotism for what it really was so that all the people could take warning? Or was he even trying to trap the young Medici into following his precepts and thus getting themselves thrown out of Florence by an outraged populace, so that Machiavelli's republican party could get back in? Was he thoroughly immoral in what he said-or simply amoral-or was he sketching a new sort of morality-or was he beneath it all as thoroughly moral as any medieval schoolman, but simply disillusioned with the way things actually were in his day? ${ }^{11}$

I know you will expect me to answer these questions with some nice neat formula, but I cannot. Nor do I know anyone that can. All of these theories about the meaning of Machiavelli's Prince were broached before the sixteenth-century came to a close, and all of them are in one way or another still alive today. Very recent research, however, has opened up some exciting new perspectives on the development of Machiavelli's thought after 1513, and I think it is possible to report a common-sense view of the significance of Machiavelli's thought that represents a sort of scholarly consensus. ${ }^{12}$ 
The Prince was written at white-hot speed in the fall of 1513. Into it went a good many disparate, and even contradictory, emotions and desires: resentment about his misfortune, disillusionment with legal and moral ways of doing things if this was where they landed you, desire to understand what had happened and how to avoid its happening again, desire to show off his political perspicacity to the new rulers of Florence in order to get his job back, a hope that out of writing some good would come-to him, to Florence, to Italy, perhaps even to posterity. In every chaptersome more clearly than others-he was trying to do two things at once: to understand and to reform. The two were related in a simple enough way: without understanding there could be no reform. The reason why reform schemes of intellectuals have invariably failed in the past, he is convinced, is that they have not been founded on politics as they actually are. $\mathrm{He}$ is acutely aware that he is breaking with tradition, with the "Mirror of Princes" literature which urged princes to act like good men and assumed everything would be all right if they did. "My intention being to write something of use to those who understand, it appears to be more proper to go to the real truth of the matter" than to imaginary states which have never existed, he says. What is done is so far removed from what ought to be done that anyone who wants to seize and hold power must "learn how not to be good." The Prince is a sharp but desperate appeal to certain fellow Florentines in high places-desperate because it appeals to men who have forgotten God and who have over-civilized man-to play the beast, in order to gain a certain measure of civic independence and individual dignity. It is all too easy to point out the glaring flaw in the argument. If the goal is really "to found a new realm and 


\section{The Intellectual as Social Reformer}

adorn it with good laws, good arms, good friends, and good examples," as chapter 24 seems to suggest-and this is estimating the goal at its best-will this end be achieved by the means suggested or will the means corrupt the end? Does obsession with the power factors involved in any political situation result in a regime adorned with "good laws" and "good examples," or does it result merely in irresponsible depotism and more corruption?

Machiavelli never really faced up to this question, but he was too intelligent to ignore it entirely. Whether by original design or not, The Prince became a sort of "Part I" to a larger work in Machiavelli's mind, a book on republics. In 1514, the year after he finished The Prince, Machiavelli was again bored. He wrote Vettori he was not reading the ancients or discoursing on the moderns any more because in spite of advancing middle age he had fallen in love again. But the pull of his old interests was stronger even than the delights of Venus. By 1515 he seems to have been visiting the city regularly to discuss the classical historians with congenial friends in the Rucellai gardens, and between 1515 and 1517 The Discourses on Livy had taken shape.

Felix Gilbert sees evidence of development from the "realism" and contemporaneity of The Prince to the "idealism" and classicism of The Discourses. ${ }^{13}$ As Machiavelli got further away from his political career in time, he became more of an intellectual and a scholar. Influenced by his humanist friends, he saw things in larger perspective and began to elaborate his long-term ideal in a lengthy commentary on the classical historian Livy. The Prince was for a moment of political corruption and crisis. The Discourses were to be for a better time, for all time. The ideal, of course, was the Roman Republic. The Discourses were 
concerned with the reasons for Rome's greatness and (by implication) the rules for success which apply to any state. Machiavelli, although probably not an atheist, had eliminated God from any effective part in history. He had eliminated eternity and infinity as the criteria by which political success is to be judged, and so was left with duration in time and extension in space. Rome was great because her regime lasted so long and because her rule extended so widely. Careful study of her history would reveal general rules for success which could be compressed into maxims and applied to the contemporary situation, since human nature never changes and history constantly repeats itself. That is, the same human beings will be continually going through the same typical political experiences in the future as in the past-and if you know the rules of the game and the recordbook, you will naturally do better than if you don't.

"I have resolved to open a new route, which has not yet been followed by anyone," Machiavelli writes at the beginning of The Discourses. ${ }^{14}$ If the results are effective, he adds, "I shall at least have shown the way to others, who will carry out my views with greater ability, eloquence, and judgment." What is this "new route"? It is the serious study of history with a view to developing a science of politics as a yardstick for social reform. Everyone reads and admires the ancients, he says, but no one does anything about his reading. The trouble is that men read history for fun when they ought to read it for profit. Machiavelli hopes that those who read his book will derive "those advantages which should be the aim of all study of history." By "advantages" he means both knowledge and inspiration: knowledge of the rules for political success (meaning the power to endure and the power to expand), and inspiration to follow these rules 
through the illustrious example of the ancient Romans, both as individuals and as a people. He concludes his preface to the Second Book on a poignantly personal note, the perennial hope of the man of action turned intellectual: "It is the duty of an honest man to teach others that good which the malignity of the times and of fortune has prevented his doing himself; so that among the many capable ones whom he has instructed, some one perhaps, more favored by Heaven, may perform it."15

The "new route," with all its presuppositions and surprising implications, is all compressed into one arresting paragraph, which merits quoting in full:

Whoever considers the past and present will readily observe that all cities and all peoples are and ever have been animated by the same desires and passions; so that it is easy, by diligent study of the past, to foresee what is likely to happen in the future in any republic, and to apply those remedies that were used by the ancients, or, not finding any that were employed by them, to devise new ones from the similarity of events. But as such considerations are neglected or not understood by most of those who read, or, if understood by these, are unknown to those who govern, it follows that the same troubles generally recur in all republics. ${ }^{10}$

What Machiavelli seems to say here is that because human nature is always the same and because history goes round in cycles, knowledge and prediction are possible. But since the endless revolution in cycles seems to depend on men's ignorance of the process, knowledge of its rules and "remedies" may somehow break the cyclical process and history may straighten out into progress in a straight line. Whether he meant to say this or not, I am not sure. The important point is that Machiavelli was trying to use the best of the scientist's and the humanist's approach to truth, in an age which knew little real differentiation between them. The humanist finds wisdom and insight in tradition, and values 
continuity; the scientist finds new truth in careful observation and rational analysis, and values independence from tradition. Machiavelli went back to the ancients as authority, like a good humanist, and found in them the hope of developing a science of political behavior, like a good scientist. He had the humanist's belief in the power of direct inspiration from historical study, and the scientist's belief in the power of detached observation and rational interpretation. He was more of a scientist than any political writer of his day, more of a humanist than most political scientists today.

It is important to note, however, that it is Machiavelli the humanist rather than Machiavelli the scientist who is alive today. The carefully-elaborated structure of political generalizations, theorems, and maxims which he erected with such assurance has crumbled away. It never became the foundation for our modern social sciences, which have found other more carefully-tested supports. It was too early to found an experimentally grounded science of man. But to the practical politician and the statesman, to the self-seeker and the public benefactor alike, Machiavelli the humanist, the political artist, the clear-sighted but hot-blooded interpreter of power politics is still very much alive. Both dictators and democrats read him, scholars and men of affairs pay tribute to him, even theologians now appreciate him. Why? What did he really accomplish that was so important? What were his strengths and limitations as seen from four centuries away?

I suppose the answer is that he really did find a "new route," a new intellectual and moral framework in which to set the confusing political developments of his day-a framework so satisfying to many political thinkers and actors 


\section{The Intellectual as Social Reformer}

that it still in use today. This new perspective might be set down somewhat summarily as follows:

The world of men in which we find ourselves is a treacherous, constantly-changing affair. Whether it is ultimately an ordered cosmos we do not know, but it does not look as if it were. Man is alone in this world and on his own. Most men are ignorant, ambitious, ungrateful, and not to be trusted. Among individuals and groups there is a constant struggle for power. Human desires are limitless. When ambition ceases to drive men on, fear takes over and does the job. Democracies and republics are just as insatiable for power under certain circumstances as dictatorships and depotisms. There are no "safe" courses in diplomacy and politics, only choices between evils and dangers. In this world there are a few-only a few-who have intelligence, courage, and public spirit. If these few will only exercise their brains and wills, and not be squeamish about the means they use, perhaps some limited good may be achieved, some stability gained in the midst of flux, some virtue in the midst of corruption. The best we can do is to study the repetitive patterns of our social existence as carefully as we can, decide upon the best courses, choose our ways with intelligence and boldness, and stick by our choices with determination.

Machiavelli saw the essentially demonic nature of power. He saw that power is never tamed by moral precepts and that often the worst anarchy is the result of the best intentions. He never doubted the value of personal morality, as his own career proved, but he came to feel that there is a political morality which has its own autonomy and which must inevitably cancel out personal morality in moments of crisis. He was a ruthless critic of all who dreamed of ends without any concern for whether the means existed to attain 
them-and of all who saw how to attain their ends but lacked the courage to act on their insight. "It very seldom happens that a good man is willing to become prince by bad means, though his object be good," he remarked ruefully. "Men know not how to be gloriously wicked or perfectly good.... And when a crime has something of grandeur and nobility in it, they flinch." 17

This last sentence suggests some of the classic caveats about Machiavelli as political analyst and reformer-because men have been "Hinching" from his doctrine ever since they learned of it. The new political morality which he sketched out was purely pragmatic, to be tested not by intentions but by results. There was little if any continuity between this political morality and the traditional personal morality of the classical and Christian traditions. Machiavelli's state, it has often been remarked, was as isolated, as self-sufficient, as proud and free-standing as a Renaissance statue. He found "a new order" as he hoped, but it had too little continuity, too little organic relationship with the old for healthy, wellbalanced growth. He saw two of the dimensions of power, the physical and the intellectual. And perhaps he tended to exaggerate both: not only the power of the pen (exaggeration here is par-for-the-course with intellectuals in general), but also the power of the sword (exaggeration here is what happens when intellectuals lean over backward to prove that they are tough-minded men of affairs: "Scholars and literary men often seem more given to the inverted idealism of Realpolitik than working diplomats," Garrett Mattingly observes $\left.^{18}\right)$. But in a sense Machiavelli missed the third dimension of power, the moral dimension. It is possible to argue that Machiavelli, the consummate realist, the resolute facer of thing-as-they-are, had one blind-spot which made 


\section{The Intellectual as Social Reformer}

him unable to see the reality of moral and spiritual forces in the lives of men.

This leaves us with a final paradox. The penetration and profundity of Machiavelli's thought is integrally related to his experience as a human being, as is all great thought in the humanities. What a man has learned in the venture of living, as husband, father, and citizen, has a great deal to do with how deeply he can penetrate as philosopher or poet or artist or student of literature, or even as historian and political scientist. Machiavelli's experience as a man and as a bureaucrat, taken together with his dismissal from office, were the origins of his political thought, both in its greatness and in its limitations. Two of his most famous maxims-that it is necessary on occasions for a prince to break his faith, and that deliberate frightfulness is often a good thing-are evidences of a sort of emotional high tension which can be traced to his political disappointment (there is hardly a trace of either of these doctrines in his letters before his dismissal in 1512). So it could be said-with the soundest psychiatric backing, I am sure-that if Machiavelli had only got his job back, or had learned to accept the frustration of his political ambition with more equanimity, we would have had a less cynical, less amoral, and better balanced political doctrine from him. I agree. But the paradox is that in this case he would never have written it down at all.

\section{Thomas More}

Some five years after Machiavelli's death, a close student of his little book on The Prince, Thomas Cromwell, became the chief minister of King Henry VIII of England. His only rival for the King's favor, Thomas More, had resigned as 


\section{The Rice Institute Pamphlet}

Lord Chancellor the day after the clergy acknowledged Henry as Supreme Head of the Church of England in place of the Pope (May, 1532). Cromwell brought More a message from the King soon after his resignation, and they had a lengthy talk. At the end, More said: "Master Cromwell, you are now entered into the service of a most noble, wise, and liberal prince; if you will follow my poor advice, you shall, in your counsel-giving unto his Grace, ever tell him what he ought to do, but never what he is able to do. . . For if a lion knew his own strength, hard were it for any man to rule him." More's biographer remarks that we can think of this interview "as one where the Utopian faced the Machiavellian, provided we use these words without prejudice.... It was not necessarily idealism facing villainy."10

Whatever it was, the wider issues behind this confrontation-moralism vs. realism, what ought to be $v s$. what ishave fascinated students of Utopia and The Prince all the way from Jean Bodin in the later sixteenth century to Gerhard Ritter in the twentieth. Ritter, a non-Nazi but nationalistic German historian writing just at the opening of the Second World War, used Machiavelli and More as pegs on which to hang reflections on the contrast between continental and English political thinking, between German realism born of continental power politics and English moralism born of insular isolation..$^{20}$ Bodin, writing four centuries earlier in the midst of a civil war, tried to find his own balance between Machiavelli's disillusionment and More's never-never land. I have found students unfailingly interested and aroused to battle by my asking them to assume that Machiavelli's Prince and More's Utopia actually exist, then to imagine what happens if the Prince lands on Utopia. Will he be helpless, or will he have the place organized in a 


\section{The Intellectual as Social Reformer}

few months? So long as men continue to be worried about the relation between might and right, between politics and morality, these two thinkers, who were working away at their rival schemes of reform during the same years about a thousand miles away from each other, will remain alive in the memory of Western society.

The political and intellectual environment in which the young Thomas More grew up was of course different from Machiavelli's Florence. The underlying problems were the same: the decay of medieval institutions, the growth of strong centers of political power, and the spread of capitalistic practices in the economy. But there was more continuity with the immediate past in More's England, and the social tensions resulting from change took different forms. Henry VII, the first Tudor, had pretty well scotched the danger of feudal anarchy by strengthening the monarchy, building up a surplus in the treasury, holding a tight rein on the nobility, and keeping England out of war abroad. His methods were not always scrupulous, but it took hardheaded policies to deal with pretenders to his shaky throne and with overmighty subjects. Since the end result was peace and order and surcease of civil war, Machiavelli would have approved-and so have most modern historians. But a sensitive contemporary might well have been dismayed by Henry's financial exactions, his enforcement of long-forgotten laws to raise money, and his practice of getting a grant from Parliament for a war, then calling off the war and keeping the money. The same sensitive observer might well have been disturbed for different reasons by the adventurous foreign policy of his son, Henry VIII. Within five years of coming to the throne in 1509, Henry VIII had squandered his father's surplus on a futile war with France, the chief 
motive of which was to gain glory for the young monarch.

Machiavelli, you will remember, was impressed by two things as he was growing to maturity; the factional fights which tore his native city to pieces, and its weakness with respect to the big powers of the day. More, on the other hand, was a subject of one of the better-run national monarchies of the sixteenth-century. His country had just come through a time of troubles but was now strong, united, and in no danger of invasion or conquest. In fact, if there was any danger, it was that England would let her recovery go to her head and dissipate her new-found strength in continental adventures. There was little danger any more of organized feudal revolt or lawlessness. But there were disturbing signs that the energies of the ruling class, which had once gone into the wars with France and the Wars of the Roses, were now going into economic exploitation of the people and cut-throat competition for favor at the court. More was the son of a London lawyer, and he spent some years in his teens as a page in the household of Cardinal Morton, a churchman of integrity and devotion. It was natural for him to look at the social problems of his day through the eyes of a city-dweller or of a clergyman. The danger, as he would see it, was not so much anarchy as tyranny, not so much urban factions as feudal greed and arrogance, not so much national weakness as national aggressiveness.

The intellectual influence of overwhelming importance on More was Christian humanism. ${ }^{21}$ It is hard today to recapture the enthusiasm of the Christian humanistsReuchlin, Erasmus, Lefèvre d'Etaples, John Colet, and More himself-because what they believed possible seems utterly unrealistic as we look back on it. They believed they could 
save their society by reviving the best in both classical and Christian antiquity, going back to Plato and the Gospels, reconciling the two traditions, and stripping off all medieval accretions and distortions. They were Christian intellectuals with an infectious belief in the power of good scholarship and proper education. They thought that if men only knew what Socrates said and what Jesus preached, if men could only be made to see the gulf between apostolic Christianity and sixteenth-century Christianity, reform would inevitably follow. No one could stop it, once men of intelligence and good-will had been exposed to the best that had come down from ancient Greece and Palestine. Erasmus met More on his first trip to England in 1499, and for the next twenty years he and More and John Colet were in close touch with each other, plotting the strategy of a Christian humanism which would overthrow scholasticism, restore knowledge of the best in pagan and Christian antiquity, and ultimately revive a corrupt and war-torn Christendom.

Practically all of these men were pure intellectualswriters, teachers, scholars, with no professional responsibility for carrying into practice the reforms they advocated. Thomas More was the outstanding exception: a deeplydevoted Christian and a scholar in all his instincts, but one who was called early to a busy and exhausting career as a lawyer and public official. The strong streak of Christian piety in him almost led him to become a Carthusian monk, and he never entirely put aside the possibility, always admired the monastic ideal, and secretly wore a hair-shirt next to his skin all his life. But he remained a layman, married, begot a large family, and followed in his father's footsteps in the law, soon combining his private practice with the office of Under Sheriff of the City of London. The duties of 
this office are not clear, but More's chief job seems to have been to represent the interests of the London merchant community in legal relationships with the Crown. Henry VIII and Wolsey came to know the young lawyer and covet his services for the Crown. Just when the King began to press More to enter the royal service we do not know, but we find him a member of an embassy to the Netherlands in the summer of 1515, still merely representing the City's interests on an ad hoc mission and not yet a royal official.

The embassy proved to be an important event in More's life. Apparently there were lulls in the negotiations (as there always are) while both sides waited for further instructions from home. More visited an old friend, Peter Giles, in Antwerp, and there was time for talk, for thought, and for writing. Somehow, away from his family, away from his native land, temporarily unoccupied by the press of business, he began to let his imagination take flight. The world was surely in a parlous state, as perhaps it always had been. More had seen its seamy side as a lawyer. He was a good lawyer, but hated most of what he had to do. He was peculiarly sensitive to what happens to the little man in the toils of the law and the clutches of the rich. He knew that the economic revolution which had struck England-the conversion of arable land to pasture because of the profit to be made from sheep-farming-was causing misery and suffering among the poor. Unemployment led to vagabondage, vagabondage to thievery; then the thieves were punished by a savage death penalty-which did not stop the thievery or save the souls of the victims. Meanwhile the rich squandered the profits of their exploitation and monopoly on clothes, servants, and luxuries. Everywhere pride, greed, and idleness-and among princes, nothing but a ceaseless and 
senseless struggle for more gold and more territory. Not a pretty picture-and surely an excuse for cynicism.

How would it look, however, to a Christian humanist? There were certain unexploited resources in the classical and Christian traditions which might be utilized to help solve sixteenth-century problems, if only they could be brought vividly before men's imaginations. This matter of "mine-and-thine," for instance, which was at the root of all the trouble: Plato knew that if his governors were to develop any true sense of community among themselves, private property must be denied them. The first apostles held all their goods in common, and the first rule of all truly strenuous Christianity communities ever since had been renunciation of property. Granted that man will always remain a sinner. Still, his nature is to a large extent the product of his environment. What if he should take seriously the ideals of Plato's Republic and the medieval monastery? Wasn't it theoretically possible to build a society based on communism of goods in which pride in its way of life and satisfaction with the results would curb the natural tendency to greed of its individual members? Perhaps such a society actually existed, now, somewhere in the vast expanses of the world recently opened up to wondering European eyes since Columbus's momentous voyage twenty-three years before. At any rate, the startling tales of mariners back from the New World and walking the streets of Antwerp suggested that this sort of thing was not beyond believing.

This is a not altogether fanciful account of what went through More's head in the summer of 1515 as he whiled away the time at Peter Giles's in Antwerp. It is based, of course, on what came out of his head at the end of the summer: namely, a manuscript describing the people and 
customs of "Utopia," and representing Book II of what we have in print today plus the first five pages of Book I as preface. ${ }^{22}$ It was a startingly original combination of daring imagination and hard realism, lightened by turns of sheer wit and horseplay. Almost every feature of Utopian life and thought (except the more obviously humorous bits) was designed as a remedy or palliative to some concrete social evil which More knew at first-hand. His realistic lawyer's grasp of his own society, its economic, social, and political problems, lay behind every flight of the imagination. He drew on his wide knowledge of classical and Christian literature for ideas, but there was no literal copying of tradition anywhere. For instance, communism in Utopia is the way of life of the whole nation, not of a few governors (as in Plato) or of an isolated group (as in the monastery); yet there is still much of Plato's and St. Benedict's spirit in it.

Not only in detail, but also in the architecture of the whole, the second book of Utopia is a Christian humanist's carefully-developed remedy for the three key sins of English society-sloth, greed, and especially pride-as the brilliant little study of J. H. Hexter shows so convincingly. ${ }^{23}$ Everyone is compelled to work in Utopia so that idleness may never become a badge of social privilege. Greed is nipped in the bud by providing everyone with economic security. And pride is given nothing to feed upon, at least in the individual's life. With true Christian insight, More rates pride as a deadlier sin than greed-“the princess and mother of all mischief," in fact. Without pride, without the limitless desire to outshine other persons, to show off, to out-spend and out-consume all social rivals, to play God on earth, greed would be comparatively easy to handle, More seems to suggest. At any rate, the strict and dreary egalitarianism 
of Utopia is designed just as clearly to exterminate pride as it is to curb avarice.

We need not enter into the tangle of later arguments about the meaning of Utopia-whether it is more "humanistic" or more "Christian," whether it looks back to the Middle Ages or forward to Karl Marx, for instance. The question whether More was fundamentally serious or just writing for fun, however, is relevant. There seems to be little doubt, since the fine biography of $\mathrm{R}$. W. Chambers some twenty years ago, that More's intent was serious: to show how an ideal society based on reason alone without the benefit of revelation, might still put to shame a Christian society which did not live up to the truth revealed to it. The literalist can of course walk heavy-footed through Utopia and show you that More didn't mean this or that seriously, and the pedant can prove that it's all a story told by an old traveler and that More never said he believed it. But there is too much in both the design and detail of Utopia that has the ring of passionate sincerity about it for any thoughtful reader to doubt that the writer was trying to get something across. If we can still argue about what Erasmus was trying to do in his Praise of Folly and Machiavelli in The Prince, it is natural to wonder about what More meant to accomplish by picturing an imaginary island, remarkably like England in geography and remarkably unlike England in social customs, supposedly in actual existence here and now, removed from Europe not in time but simply by spacewhich was quite different from either Plato's Republic or Augustine's City of God, incidentally. I think he was trying to say: stretch your imaginations, exercise your fancy, get out of the mental ruts men have been in for centuries, stop reconciling yourselves to social evil as inevitable, and keep 
steadily before you the picture of what might be as the measure of what is. You may not, and probably will not, set up communism of goods overnight, he seems to say, but if you have seriously considered the advantages of a communist society, at least you will never again look on private property as an absolute, an untouchable right to be defended against all attempts to limit it.

One of the effects, if not one of the purposes, of Utopia was to answer a man whom More had never read, namely Machiavelli. Parts of Utopia, it has been remarked before this, read like a comment on The Prince. In judging crimes, the Utopians look not to the overt results but "count the intent and pretensed purpose as evil as the act or deed itself." ${ }^{24}$ Agreements between princes are kept of course in Europe, says the narrator Raphael with obvious irony, but in the new world where Utopia is situated, princes find loop-holes in treaties by crafty dodges which they would loudly condemn if used in private dealings. So out there it looks as if there are two kinds of justice:

... the one meet for the inferior sort of people, going afoot and creeping low by the ground, and bound down on every side with many bands so that it shall not run at rovers. The other a princely virtue, which like as it is of higher majestie than the other poor justice, so also it is of much more liberty, as to the which nothing is unlawful that it lusteth after. ${ }^{25}$

The result is that the Utopians make no formal alliances whatever in the belief that "men be better and more surely knit together by love and benevolence than by covenants of leagues."26 Only two years before, Machiavelli had remarked, "The experience of our times shows those princes to have done great things who have had little regard for good faith .... and who have ultimately overcome those who have made loyalty their foundation"; therefore, "a pru- 
dent ruler ought not to keep faith when by so doing it would be against his interest." "Everybody sees what you appear to be, few feel what you are," Machiavelli concluded; "the end justifies the means"; therefore let a prince aim at "conquering and maintaining the state, and the means will always be judged honorable and praised by every one, for the vulgar is always taken by appearances and the issue of the event- and the world consists only of the vulgar. ..."27 The issue between personal morality and "princely virtue" has never been stated better.

The chief difference between Machiavelli's thought-world and that of More, however, cannot be illustrated by direct quotation. It has to do with time and change. Utopia is a completely static society. Since its foundation by King Utopus there has been no significant change, no development, no "history" in fact, and presumably there will be no change in the future. The assumptions underlying Utopia are: first, that evil is essentially social as well as individual, and so any effective attack on it must be through the creation of a new social structure, a new environment; second, this environment, once it is created, will curb and control individual tendencies to evil, even if it will not entirely root out human sin; and third, there are timeless rules of reason which may be discovered and used in designing this new social structure. With much of this Machiavelli, especially in The Discourses, would agree. But Machiavelli could never escape from the time dimension as the Utopians succeed in doing. His test of a prince was ability to change with "times and circumstances," his test of a republic was ability to endure in time and expand in space. Nothing is at rest in The Prince and The Discourses; everything is at rest in Utopia. To Machiavelli the real world is a continuous strug- 
gle for power between competing vitalities; to More, in Utopia, it is a world in which power can be controlled and disciplined, nay even rendered harmless. Machiavelli is consciously an intellectual revolutionary, always striving for a "new order," a "new route." More is a conservative who pictures a society, built on reason, devoting an enormous part of its energy simply to preserving the status quo.

More's picture is worth examining more closely. Utopia is an artificial island-it was King Utopus who dug the fifteen-mile channel that separates it from the continent. Geographical isolation both makes possible and intensifies the Utopians' psychological isolation from their neighbors. What holds the rather loose federation of Utopian cities together is national sentiment, as we would call it-pride in the Utopian way of life, which the inhabitants know is quite different from that of others and which must thus be jealously protected and preserved. ${ }^{28}$ There are all kinds of ingenious devices to preserve the status quo, to keep the number in each family constant, to keep the population at a constant level, to balance trade, and to maintain international peace so that the Utopian welfare state may not be disturbed in its enjoyment of the good life. The Utopians are far more wealthy and powerful than any of their neighbors, and so they go to war only in "just" causes. The list of "just" causes is rather long, it must be confessed, and includes resistance to Utopian colonization of backward areas and injuries done to merchants of allied powers. The Utopians use their overwhelming power only to execute right and justice-and in Raphael's account of it, their neighbors seem to grant the Utopians' moral and cultural superiority as good grounds for their policy. In fact, there is a strong streak of moral righteousness in all that they do. 
They are harder on their own condemned criminals than on their foreign slaves "because they being so godly brought up to virtue in so excellent a commonwealth" still went wrong. ${ }^{29}$ Their principal objective in going to war is "to obtain that thing, which if they had before obtained, they would not have moved battle"-an excellent principle too seldom followed by belligerents. But, the account continues, "if that be not possible, they take so cruel vengeance of them which be in the fault, that ever after they be afeared to do the like." ${ }^{30}$ Because Utopian manhood is so precious, they prefer to fight by the crafty use of money and propaganda, and by tricks which would delight a Machiavellian. They use their friends' and allies' troops before their own. But if they are finally forced to fight, they fight hard, knowing they are in the right, and they impose stiff indemnities on their defeated victims.

It took German historians like Ritter to point out that this insular self-righteousness, which is such an amusing characteristic of Utopian policy, is not unlike some later aspects of British foreign policy. ${ }^{31}$ With no land frontier to defend, it was hard for Englishmen to understand the Machiavellism of continental powers which were caught in the continuous struggle for power, and easy for them to read the moral law to their obstreperous neighbors. The unconscious assumption of English statesmen often was that a free people's acts could not be anything but moral, whereas the acts of continental despotisms would ipso facto be immoral. Further, it was natural for the British to equate morality with preserving the status quo and immorality with upsetting it. It is certainly not fair to burden More with any responsibility for forming later British policy. But it is sound to point out, as Ritter does, that More was thoroughly medieval 


\section{The Rice Institute Pamphlet}

in his belief in timeless standards of right and justice, that he thought the use of power justified only as a means of enforcing right or justice, and that war made sense to him only as an instrument of justice meting out punishmentnot as a more or less natural result of competing wills-tolive, as it looked to Machiavelli. More believed that power could be harnessed and tamed by righteousness. But his later German critics are justified in asking the embarrassing question: how would those neighboring backward peoples really feel about the high-and-mighty Utopians, with their gold which they never enjoy, their "dumping" policy in foreign trade, their big citizen army, and their high moral principles? Is the struggle for power abolished by imagining it out of existence? Or does it slip in by the back door after the moralist has bolted and barred the front? More's Utopia is the work of a conscientious Christian humanist, humane and civilized in spirit. But there is a streak of moralism and self-righteousness in it that is related to the later More who conscientiously supported the burning of heretics.

Now let us return to the author of this lively description of an imaginary island, back from the embassy to the Netherlands at the end of 1515, and leading his friend Peter Giles to believe that the manuscript would very soon appear in print. It did not appear for over a year, and when it did, it was expanded to include a marvelous dialogue between the narrator, Raphael Hythlodaye, Peter Giles, and Thomas More himself. This was sandwiched in between the first five pages of the original version and the actual description of Utopia. Why was this dialogue added, and what does it mean in the light of all we know about More himself?

The first to answer these questions convincingly, it seems to me, has been Professor Hexter in the study I have already 


\section{The Intellectual as Social Reformer}

mentioned. ${ }^{32}$ In brief, there is strong indirect evidence that More was wrestling hard in the summer of 1516 with the most important problem a Christian intellectual can face: to what extent must he be responsible for carrying out his ideas himself if the opportunity is offered? Erasmus was with him in the summer of 1516 , and the presumption is that there were long talks between them about Henry VIII's pressure on More to become a privy councilor. No one knows how Erasmus argued, but the way he lived out the answer himself is well known. The calling of a Christian scholar is a high one, he might have maintained. It takes all of a man's time and energy. Furthermore, it requires absolute independence and integrity. You cannot be committed to spending a certain number of hours a day at court and still study and write. More important, you cannot be the servant of a King and still think you are free to speak and write as your mind and conscience dictate. Either you commit yourself to the truly important task, the re-education of Christendom through restoration of the best in classical and Christian antiquity, or you become so entangled in worldly affairs that your tongue and pen lose their cutting edge, and you no longer are an intellectual and a reformer worthy of the name. I repeat: Erasmus may or may not have spoken thus to More, but this was really what he had bet his own life on-and More himself had strong sympathies with this point of view. Could he not argue that to have written the description of Utopia was enough? Let others read it and work out the applications. The important thing was the intellectual's task of seeing things clearly and presenting the truth persuasively.

There was another side to More, however-the lawyer, the man of affairs, the realist. In Utopia he remembers that his 
old mentor, Cardinal Morton, had served Henry VII well. "The King put much trust in his counsel, the weal public also in a manner leaned unto him," he says. ${ }^{38}$ In sixteenthcentury Europe, kings had the power, and to counsel kings successfully was to put new ideas into effect and to bring about the public good. How could a Christian humanist, who honestly believed in the ideals embodied in Utopia, refuse the opportunity to implement them by counseling a king if offered the chance?

All this is argued out in the dialogue between Raphael Hythlodaye and More in the First Book of Utopia.$^{34}$ With his vast experience of other societies, Raphael should offer his services to a king, says More. Never, says Raphael. Imagine me in the French King's Council. The question for discussion is how the king can hold onto Milan, recover Naples, conquer Venice, gobble up the Netherlands, and still avoid a stab in the back by England. If I stand up and say: Turn over a new leaf, gentlemen; learn a new lesson; my advice is to stay out of Italy and Flanders entirely; there is enough to do in providing good government for a large country like France without wasting the nation's blood in foreign conquest-who would listen to me in such a hard-headed group? In such a situation, who listens to a man who brings up something he knows was done in times past or has seen done in some other place?

Well, says More, I did not mean that you should make yourself ridiculous by always proposing impossibly idealistic policies. This "school philosophy" naturally has no place in royal councils. But there is a more tactful and diplomatic way, a "philosophy more civil." This is to "handle the matter wittily," and to see that what you can't turn to good still does not come out too badly. "You must not leave and forsake 
the commonwealth; you must not forsake the ship in a tempest [simply] because you cannot rule and keep down the winds," he says to Raphael. ${ }^{35}$

Raphael is unconvinced. Either he must speak the truth or remain silent, he says. He is afraid that More's "crafty and subtle" approach really amounts to compromising with the truth. Furthermore, it is almost impossible to conceal your real opinions in a royal council. Unless you go along with wicked and foolish decisions of the majority, you will quickly be accounted a spy or even a traitor. And if you do go along with the decisions, the wickedness and folly will of course be attributed to you by the outside world. This is the last word, and Raphael, representing More's "pure intellectual" side, speaks it. But the dialogue is obviously the work of a man deeply divided in mind and heart.

This was where the argument was left when Utopia went to the printer in Louvain under Erasmus' supervision in December, 1516. For two more years More held out. Then what the English weathercasters call a "bright spell" seemed to pass over the political landscape. Wolsey began to defend the poor against enclosures, the King became strongly peaceminded, and the future looked bright. ${ }^{36}$ More entered the royal service and soon he was privy councilor, Speaker of the House of Commons, and finally Lord Chancellor. His career as an independent Christian humanist, as a reforming intellectual, ceased (as he had seen it would) and his preparation for martyrdom began (as he had dimly sensed it would). Raphael's predictions came true, one by one. More made it clear to the king that he disagreed with the divorce proceedings, but that he would remain silent in public. Thomas Cromwell, however, with his clear Machiavellian vision, saw that it was More's refusal to say what he could 
not believe that was "making others so stiff as they be." And so, because he stood in the way of a revolution, More was condemned for treason on perjured testimony and sent to the block-twenty years after Utopia was conceived and three years after the appearance in print of Machiavelli's Prince and The Discourses. In a sense he had deliberately ended his career as a Christian humanist and reformer when he entered the royal service, in order to attest his belief that an intellectual must be ultimately willing to put his ideas to the test of practice, and that a Christian, like his Master, must be ready to be crucified for his beliefs.

\section{Contemporary Echoes}

I have tried to sketch the contrasting development of the two great political analysts of the early sixteenth century. Each in his own way tried to probe to the roots of the bewildering social evils of his day. Each tried like a good intellectual to see things whole, to explore every relevant resource in tradition, to use every important piece of evidence from history and contemporary experience. In trying to see things whole, they got the desire to set things straight. Or perhaps it is just as correct to say that their desire to set things straight drove them to the mental effort of seeing things whole.

They did not reach the same conclusions, of course. They differed-profoundly and fundamentally-in spite of much in common. And this points up the truth-or is it a truism? -that humanistic knowledge is not like scientific knowledge. It does not accumulate, like the sedimentary layers which eventually form a single, solid rock. Rather it grows like a group of organisms which are like each other and yet each one unique, intimately dependent on their surrounding environment of light, air, and nourishment, always subject to 


\section{The Intellectual as Social Reformer}

the possibility of annihilation. Where insight and evaluation are involved, the humanist turns to the best he knows of ancient wisdom on a subject and uses this wisdom as an essential intellectual resource in a fresh and realistic analysis of his own particular historical situation. Times change, but are never altogether different. The world of Plato, the world of Thomas More, and the world of today are very different, but they are not so different that Plato and More are irrelevant to us. A modern physicist need not know much about Aristotle or how he arrived at his ideas of motion. To be sure, he builds on Newton's laws, but he cares little about how Newton came to formulate them. The historical and biographical detail which has formed the substance of these lectures, however, is important to the humanist because the way intellectuals become social reformers, the way their human experience contributes to their social insight, is still relevant to us. And their conclusions are still alive in a way those of the medieval astrologer are not alive for the modern scientist. The antinomy of realism and moralism in the analysis of politics, for instance, must be argued through for each generation, in the light of its particular historical circumstances and needs. In their day Machiavelli and More seemed utterly irreconcilable. To Machiavelli the ceaseless struggle for power must be accepted as one of the brute facts of life. You can learn how to use it, he might say; and in certain ideal circumstances you can balance power against power and so attain a certain stability and order; but you can never tame power, never outlaw it or ignore it. To Thomas More in Utopia, on the other hand, the struggle for power may be so curbed and contained by the proper structure of law and right that for all practical purposes its capacity for evil can be forgotten. The causes of ambition and sedition have been so skillfully "plucked up by the roots" in Utopia that the 
society will "endure for ever" and no foreign prince will be able to shake it, Raphael says. ${ }^{37}$ And so the Machiavellian and the Utopian come down to us from the sixteenth century as symbols of an eternal contradiction. The Machiavellian sees nothing but material power and is blind to moral and spiritual forces; the Utopian overestimates moral forces and thinks he can exorcise the demon of power in the end.

From this distance, however, it looks as if we are dealing not with contradiction or paradox in the case of Machiavelli versus More, but with what our scientist friends would call complementarity. Obviously no government that ignores the pure power factors in its position will survive long-nor will one that fails to convert naked power into some structure of right. Pascal summed it up a century later in that bitter, penetrating way he had of stabbing to the heart of the matter: "Justice without might is helpless; might without justice is tyrannical. ... We must therefore combine justice and might, and for this end make what is just strong, or what is strong just. ... Being unable to cause might to obey justice, men have made it just to obey might. Unable to strengthen justice, they have justified might." ${ }^{38}$ Pascal's irony is Machiavelli's, but his underlying faith is More's.

And so the dialectic continues from generation to generation. To know the history of the argument, to know its greatest protagonists, is to add perspective and depth to our own self-understanding. Where and by whom is the dialectic being carried forward today? One would naturally look for it in the United States, the power of long isolationist tradition and strong moral beliefs, much like the Utopians in some ways, but recently shocked out of its complacency by being thrust into a deadly competition for existence with a ruthless power of equal strength. And I think you may find a hint of it at least in the writings of two distinguished statesmen who 
have also qualified at different times as intellectuals and reformers: George Kennan and John Foster Dulles. You notice I say their "writings." It is too early to judge the active careers of either, but each wrote books and articles around mid-century which were written rapidly and urgently for the general reader, to inform and to reform, much as Machiavelli's Prince and More's Utopia were written. ${ }^{39}$

In fact, there are amusing parallels here between the sixteenth and twentieth centuries. Mr. Kennan, a distinguished career diplomat, organizer of the Policy Planning Staff of the State Department, ambassador to the Kremlin and outstanding expert on Russia, was allowed to "retire" from the foreign service in April, 1953, at the age of fortynine, because the new administration had campaigned against the "containment" policy which he had fathered and so found no use for him. He has since turned to history, like Machiavelli in his retirement, and is engaged in a fulldress study of America and the Russian Revolution, the first volume of which has won wide acclaim. Mr. Dulles, it is said, had been preparing himself for the Secretaryship of State since childhood-with somewhat more zest than Thomas More prepared himself for the royal service. As part of this preparation he wrote extensively on the general subject of foreign policy before he attained his lifelong ambition in January of 1953. And so, like Machiavelli, Mr. Kennan may be considered a statesman more or less involuntarily turned intellectual. Like More, Mr. Dulles was a lawyer and intellectual who ultimately became an active statesman. As in the case of Machiavelli and More, there is much in common between them, and much in sharp dispute.

Mr. Kennan urges us to see the world as it is, not as it might be if all peoples were like the American. Power is the central fact in the world of diplomacy, and it is better 
in the long run to devise means of balancing power by oldfashioned diplomacy, he thinks, than to ignore the power factor (which is dangerous), or to rely on legalistic restraints (which is futile). "This is a hard and cruel world we live in," he writes. Other nations don't exactly see us as we see ourselves-peace-loving, law-abiding, willing to live and let live. The rest of the world is not ready to federate in a nice reasonable way as our original thirteen states did; in fact it is not even willing to preserve the status quo which is so favorable to us. The most serious fault in twentieth-century American foreign policy is what Kennan calls "the legalisticmoralistic approach to international problems": our faith in arbitration treaties, pacts solemnly outlawing war, schemes for international organization which we expect too much of and so become disillusioned with. ${ }^{40}$ Our legalism easily becomes moral superiority; our wars too readily become wars for righteousness, which means that they are total wars and can only end in total defeats-and this will spell disaster for both sides in an atomic world. We tend to apply our individual moral standards too naïvely to international affairs. "We cannot, when it comes to dealings between governments, assign to moral values the same significance we give them in personal life." We can-and Mr. Kennan fervently hopes we will-follow moral methods in our diplomacy. But personal morality can never be a valid test of the purposes of a state, nor "a criterion for measuring and comparing the behavior of different states." ${ }^{\text {"11 }}$ We would do better, he thinks, if as a people we were less eager to appear morally superior, and more willing to accept the fact that we are a great power which has to do some of the things great powers have always had to do to survive-and not be ashamed about it. Lest you think from this that Mr. Kennan is Machiavelli reincarnated, I hasten to add that he is a 
sincere Presbyterian layman and writes, "I do not wish to see the conduct of this nation in its foreign relations animated by anything else than decency, generosity, moderation, and consideration for others." ${ }^{32}$ But the affinity to the best in Machiavelli's realism is evident enough, this time rooted in a kind of Christian pessimism.

Mr. Dulles is another Presbyterian layman of a somewhat more familiar Calvinist stamp. There is much in his book War or Peace? (1950) with which Mr. Kennan would agree, but the whole tone and temper is different. He believes that "in the pattern of our own national life we can find the pattern for world peace."13 Peace can be "patterned," then, and the pattern can be found in the federation of the thirteen colonies and the drafting of the Constitution. The United States became great because of its people's moral beliefs and spiritual convictions, now unfortunately submerged by materialism. Only by recovering her faith in her spiritual destiny can America combat Communism. Where Kennan tends to emphasize the danger from Russia, the world power, Dulles tends to emphasize the threat of Communist ideology. "Power is the key of success in dealing with the Soviet leadership," he writes. But he continues: "Power, of course, includes not merely military power, but economic power and the intangibles, such as moral judgement and world opinion, which determine what men do and the intensity with which they do it." ${ }^{\text {"*4 }}$ As one reads on, one realizes that we are in a battle of creeds far more than a conflict of world powers. Mr. Dulles would have us fight like the Utopians, first by propaganda before we draw the sword. He has great faith in legal structures, moral arguments, and non-material forces. Like the Utopians, he has no doubt about who is right and who is wrong (he has often been ready to treat both friend and foe to little lectures on the subject as he steps aboard 
planes). But at his best he has the same rugged sense of right combined with realistic grasp of politics that characterized Thomas More's thinking-albeit in Presbyterian rather than papal garb.

And so there is nothing really new in the world of political thought after all. But the corollary is that the big issues are never old and stale either. I had thought that I was more or less "original" in my feeling that George Kennan represents the realistic pole of contemporary American thinking about international affairs and John Foster Dulles the moralistic, until I picked up a little book by a French-Swiss writer, M. Louis Brandt-Peltier, called Conceptions américaines de politique étrangère: Kennan, Dulles (Paris, 1953). The author draws the polar contrast between the two even more sharply than I have. America did not become great merely through her moral and spiritual convictions, he points out slyly in reply to Dulles: geographical isolation and the protection of the British navy had something to do with it. Europe prefers a "materialistic" to a moralistic America, he hints. Europeans can accept American economic superiority, he says, but Lord help them if the United States undergoes a religious reform and becomes possessed of some new sense of "Manifest Destiny" to reform the world! He concludes dryly: "What America needs most is to be enlightened, not reformed." 45

It may be that enlightenment and reform are more closely related than $M$. Brandt-Peltier thinks they are. At least Machiavelli and Thomas More thought so. To each in different ways the impulse to reform was integrally related to the impulse to understand. The intellectual as social reformer has his faults, as is perfectly evident in our two subjects themselves. $\mathrm{He}$ is apt to see the social landscape in too sharp relief of black and white, and he is prone to exaggerate the 
rationality of men. But if we are going to have reformersand we are, of course-there is a good deal to be said for the proposition that it is better to have men whose itch to change society has grown out of the scholar's desire to grasp the complexities of the social structure than to suffer under the ignorant fanatics and "dim-witted saints" (the phrase is William James's) who clutter the pages of history.

But it is time for me to leave you to think over for yourselves whether you would vote for realism or moralism the next time you have the chance. The argument is still unsettled. Your vote can still affect the results. And if you have got anything at all out of these talks, you may be conscious of Machiavelli and Thomas More peering over your shoulder as you debate the issue within yourself.

\section{E. HaRris Harbison}

\section{NOTES}

1. The Prince (Everyman trans.), chap. xxvi.

2. Machiavelli to Ricciardo Bechi, 9 March 1497, in The Living Thoughts of Machiavelli, ed. Carlo Sforza (London, 1942), pp. $79-82$.

3. See The Discourses of Niccolò Machiavelli, ed. Leslie J. Walker (New Haven, 1950), I, 16-20 ff.

4. Machiavelli to Francesco Vettori, 10 December 1513, in The Living Thoughts, pp. 101-104.

5. To Vettori, 9 April 1513, ibid., p. 88.

6. Ibid., pp. 84-87.

7. 25 April 1513, ibid., pp. 89-96.

8. 26 August 1513, ibid., pp. 96-100.

9. See note 4.

10. See J. H. Whitfield, Machiavelli (Oxford, 1947), p. 61.

11. See, e.g., Whitfield, chaps. i, iv; Allan H. Gilbert, Machiavelli's Prince and its Forerunners (Durham, 1938); Garrett Mattingly, Renaissance Diplomacy (London, 1955), pp. 165-166; Felix Gilbert, "The Humanist Concept of the Prince and the Prince of Machiavelli," Journal of Modern History, XI (December, 1939), 449-483.

12. See particularly Felix Gilbert, "The Composition and Structure of Machiavelli's Discorsi," Journal of the History of Ideas, XIV (January, 1953), 136-156; and J. H. Hexter, "Seyssel, Machia- 
velli, and Polybius VI: the Mystery of the Missing Translation," Studies in the Renaissance, III (1956), 75-96.

13. In Journal of the History of Ideas, XIV (January, 1953), 156.

14. The Prince and the Discourses, ed. Max Lerner (Modern Library ed., New York, 1940), p. 103. Trans. of Discourses by C. E. Detmold.

15. Ibid., pp. 103-105.

16. Book I, chap. xxix, ibid., p. 216.

17. Discourses, Book I, chaps. xxvii, xxx.

18. Renaissance Diplomacy, p. 40.

19. R. W. Chambers, Thomas More (New York, 1935), p. 291.

20. Machtstaat und Utopie (1940), trans. as The Corrupting Influence of Power (Hadleigh, Essex, 1952).

21. See J. H. Hexter, More's Utopia: the Biography of an Idea (Princeton, 1952), pp. 52 \&.; and E. Harris Harbison, The Christian Scholar in the Age of the Reformation (New York, 1956), chap. iii.

22. Hexter, op. cit., pp. 26-29, and passim.

23. Ibid., pp. 72-81.

24. Utopia (Everyman ed., London, 1910), p. 87.

25. Ibid., p. 90.

26. Ibid., p. 91 .

27. The Prince, chap. xviii.

28. Utopia, p. 97.

29. Ibid., p. 83.

30. Ibid., p. 93.

31. The Corrupting Influence of Power, pp. 74-89.

32. Op. cit., pp. 95, 102, 110. What follows is essentially Hexter's account.

33. Utopia, p. 20.

34. Ibid., pp. 18-20, 34-43.

35. Ibid., p. 41 .

36. Hexter, op. cit., pp. 146-155.

37. Utopia, p. 114.

38. Pensées (Everyman ed., London, 1931), nos, 298, 300.

39. George F. Kennan, American Diplomacy 1900-1950 (Chicago, 1951) and Realities of American Foreign Policy (Princeton, 1954); John Foster Dulles, War or Peace? (New York, 1950).

40. American Diplomacy, pp. $95 \mathrm{fI}$.

41. Realities of American Foreign Policy, pp. 47-50.

42. Ibid., p. 61 .

43. War or Peace?, p. 19.

44. Ibid., p. 16.

45. Pp. 179-182. 